\title{
EFEKTIVITAS LEMBAGA PEMBERDAYAAN MASYARAKAT DESA DALAM PELAKSANAAN PEMBANGUNAN DESA BULULAWANG
}

\author{
Chusnul Chotimah, Rohmad Widodo, Trisakti Handayani \\ FKIP Universitas Muhammadiyah Malang, Indonesia \\ Email: aimsuwito96@gmail.com
}

\begin{abstract}
ABSTRAK
Penelitian ini bertujuan untuk mengetahui (1) efektivitas lembaga pemberdayaan masyarakat desa dalam pelaksanaan pembangunan desa Bululawang; (2) kendala dari kinerja lembaga pemberdayaan masyarakat desa dalam pelaksanaan pembangunan desa Bululawang; (3) solusi dari permasalahan kinerja lembaga pemberdayaan masyarakat desa dalam pelaksanaan pembangunan desa Bululawang. Penelitian ini merupakan penelitian deskriptif kualitatif yang dilakukan di Kantor Desa Bululawang pada bulan Mei sampai dengan Juni 2019. Pengumpulan data dilakukan melalui observasi langsung, wawancara dengan informan, serta mendokumentasikan kegiatan. Data dianalisis melalui tahap reduksi data, penyajian data, dan penarikan kesimpulan. Serta, tahapan terakhir ialah keabsahan data menggunakan triangulasi teknik. Hasil dari penelitian ini menunjukan (1) efektivitas lembaga pemberdayaan masyarakat desa dalam pelaksanaan pembangunan desa Bululawang cukup sesuai dengan Pasal 6 Peraturan Daerah Kabupaten Malang Nomor 6 tahun 2016 tentang Lembaga Kemasyarakatan Desa. (2) kendala yang terjadi pada kinerja lembaga pemberdayaan masyarakat desa dalam pelaksanaan pembangunan desa Bululawang berupa tidak semua bagian dalam lembaga tersebut memiliki kegiatan di tiap tahunnya. (3) solusi untuk mengatasi kendala pada kinerja lembaga pemberdayaan masyarakat desa Bululawang adalah melakukan evaluasi baik kepada pribadi anggota maupun kelompok.
\end{abstract}

Kata Kunci: Efektivitas; Lembaga Pemberdayaan Masyarakat Desa; Pembangunan Desa

\section{ABSTRACT}

This research has the purpose of determining (1) the effectiveness of empowerment among villagers in Bululawang village development; (2) obstacles in Bululawang community empowerment agency in Bululawang village development; (3) Solution for this obstacles in Bululawang village development. This research method is a descriptive qualitative that has been going on in the Bululawang village office from May until June 2019. Data is collected by Observation, Interview, and Documentation from their activities method. Data is Analyzed from data reduction, data presentation, and drawing a conclusion. The last step is to validate this data using a triangulation technic. The result from this research shows that (1) Effectiveness village community empowerment agency in implementation Bululawang village development using Clause 6 Peraturan Daerah Kabupaten Malang Nomor 6 Tahun 2016 Tentang Lembaga KemasyarakatanDesa (2) Obstacles that happen in village community empowerment implementation on Bululawang village development is that not everybody has activities in their division every year. (3) The solution to overcoming challenges in village community empowerment implementation on Bululawang is to conduct evaluations for both individual members and groups.

Keyword: Effectiveness; Community Empowerment Agency; Village Development. 


\section{PENDAHULUAN}

Terdapat 3 otonomi daerah di Indonesia, yaitu yang pertama otonomi daerah tingkat provinsi, yang kedua otonomi daerah tingkat kabupaten/kota, dan yang ketiga adalah otonomi tingkat desa (Faini, 2016). Hal tersebut dipertegas dengan lahirnya Undang-Undang Nomor 6 Tahun 2014 tentang Desa. Desa memiliki hak otonomi asli berdasarkan hukum adat, desa dapat menentukan susunan pemerintahan, mengatur dan mengurus rumah tangga pemerintahan, dan juga memiliki kekayaan dan asset daerah. Oleh karena itu eksistensi suatu desa harus didukung oleh peran serta masyarakat desa.

Desentralisasi yang diwujudkan dalam bentuk Otonomi Daerah, memberikan kewenangan bagi pemerintah daerah untuk dapat mengurus rumah tangganya sendiri dalam menentukan kebijakan, perencanaan, pelaksanaan, penggunaan sumber daya yang ada di masing-masing daerah. Konsep ini dimaksudkan agar kebijakan pembangunan yang selama ini di dominasi oleh pemerintah pusat, akan dapat berhasil ketika daerah diberikan ruang untuk melakukan pembangunan pada daerahnya (Hardianto, 2016)

Dengan melihat desa sebagai wadah kegiatan ekonomi, kita harus merubah pandangan inferior atas wilayah ini, dan merubahnya dengan memandang desa sebagai basis potensial kegiatan ekonomi melalui investasi prasarana dan sarana yang menunjang keperluan pertanian, serta mengarahkannya secara lebih terpadu, sudah saatnya desa tidak dapat lagi dipandang hanya sebagai wilayah pendukung kehidupan daerah perkotaan, namun seharusnya pembangunan wilayah kota atau daerah pedesaan secara menyatu, sebab masyarakat di desa Pakatto tersebut masih kurang pemahaman tentang mekanisme peran lembaga pemberdayaan masyarakat desa dalam penyusunan pembangunan pedesaan yang lebih unggul.
Adapun terdapat issu strategis yang mengacu pada issu kabupaten yang tak lepas dari setiap peranannya antara lain : Sebagai penyalur aspirasi masyarakat, sebagai penggerak partisipasi masyarakat dan sebagai pelayanan pemerintah kepada masyarakat dalam pembangunan pedesaan terpadu (Setiawan, 2016)

Otonomi desa merupakan otonomi yang bersifat asli, utuh, dan bulat serta otonomi desa merupakan suatu pemberian pemerintah dan pemerintah memiliki kewajiban untuk menghormati segala sesuatu yang terdapat dalam otonomi desa tersebut. Sebagai masyarakat yang memiliki tatanan pemerintahan yang memiliki kewenangan dalam bertindak hukum. Desa memiliki kewenangan dalam bertindak membentuk lembaga kemasyarakatan sesuai dengan teritorial dan kondisi masyarakatnya sebagai jembatan dalam membantu fungsi pelaksanaan pemberdayaan masyarakat, pengawasan pemerintah desa dengan masyarakat, pelaksanaan pembangunan desa, pembinaan kemasyarakatan suatu desa. Lembaga kemasyarakatan desa terdiri dari Rukun Tetangga, Rukun Warga, Karang Taruna, Remaja masjid, Dasa Wisma, PKK, LPMD atau LPMK, Lembaga adat, serta Lembaga kemasyarakatan lainnya.

Tugas Lembaga Pemberdayaan Masyarakat Desa (LPMD) sebagai salah satu Lembaga Kemasyarakatan Desa terdapat pada Pasal 6 Peraturan Daerah Kabupaten Malang Nomor 16 Tahun 2006 tentang Lembaga Kemasyarakatan Desa yang meliputi sebagai berikut: (a) Menyusun rencana pembangunan secara partisipatif; (b) melaksanakan, mengendalikan, memanfaatkan, memelihara dan mengembangkan pembangunan secara partisipatif; (c) menggerakkan dan mengembangkan partisipasi, gotong royong dan swadaya masyarakat; (d) menumbuh kembangkan kondisi dinamis masyarakat dalam rangka pemberdayaan masyarakat.

Pada Pasal 7 Peraturan Daerah Kabupaten Malang Nomor 16 Tahun 
2006 tentang Lembaga Kemasyarakatan Desa dalam melaksanakan tugasnya juga menyelenggarakan fungsinya sebagai berikut: (a) penampungan dan penyaluran aspirasi masyarakat dalam pembangunan; (b) penanaman dan pemupukan kerukunan, rasa persatuan dan kesatuan masyarakat dalam kerangka memperkokoh Negara Kesatuan Republik Indonesia; (c) peningkatan kualitas dan percepatan pelayanan pemerintah kepada masyarakat; (d) penyusunan rencana, pelaksanaan, pelestarian, dan pengembangan hasilhasil pembangunan secara partisipatif; (e) penumbuh kembangan dan penggerak prakarsa, partisipasi, serta swadaya gotong royong masyarakat; (f) pemberdayaan dan peningkatan kesejahteraan keluarga; dan (g) pemberdayaan hak politik masyarakat.

Untuk menghasilkan suatu perencanaan yang baik dalam pembangunan desa maka diperlukannya kemitraan. Dalam hal ini kemitraan yang dilihat adalah kemitraan antara Lembaga Pemberdayaan Masyarakat Desa (LPMD) dengan Kepala Desa, baik LPMD maupun Kepala Desa harus saling bekerja sama dalam proses perencanaan agar pembangunan yang ini dilaksanakan dapattercapai. Kemitraan yang dilakukan oleh LPMD dengan Kepala Desa dalam proses perencanaan pembangunan bertujuan dilakukan untuk mempromosikan pembangunan ekonomi, sosial dan kebudayaan daerah pedesaan serta untuk mempromosikan kerja sama antara organisasi dalam wilayah tersebut agar bisa mempromosikan pembangunan dan memperbaiki kualitas kehidupan masyarakat setempat (Rafsanzani, 2013).

Jadi, secara umum tugas LPMD adalah mewadahi dan menumbuhkan aspirasi masyarakat desa dalam mengelola dan memajukan desa untuk menyusun perencanaan pembangunan desa secara partisipatif, melaksanakan rencana pembangunan desa, mengendalikan pembangunan desa, serta memelihara dan memanfaatkan pembangunan secara bersama-sama, menumbuhkan keaktifan masyarakat desa dalam kegiatan gotong royong, selain itu lembaga ini juga dapat mengembangkan kondisi masyarakat desa yang berkelanjutan dalam rangka meningkatkan pemberdayaan masyarakat desa. Kesimpulannya, lembaga ini memberi peran yang kuat untuk mewadahi aspirasi masyarakat desa supaya masyarakat lebih maju dalam membangun desa yang ditempatinya.

Tujuan pembangunan desa adalah untuk meningkatkan taraf hidup masyarakat desa, meningkatkan kesejahteraan masyarakat desa, kualitas hidup dan kualitas masyarakatnya, serta bertujuan untuk menanggulangi kemiskinan masyarakat melalui pemenuhan kebutuhan dasar pembangunan masyarakat, melalui sarana prasarana, melalui sumber daya alam yang terdapat dalam desa tersebut, membangun gerak perekonomian lokal sesuai dengan sumber daya alam yang ada dan sesuai dengan kemampuan masyarakatnya, serta pembangunan berwawasan lingkungan secara berkelanjutan. Proses pembangunan masyarakat suatu desa dilakukan dengan mengikut sertakan masyarakat desa dalam Musyawarah Perencanaan Pembangunan Desa (MPPD). Musyawarah Perencanaan Pembangunan Desa mengutamakan skala prioritas, program, kebutuhan, kegiatan, dan tujuan pembangunan suatu desa yang didanai oleh Anggaran Dana Desa (ADD) dan Anggaran Pendapatan dan Belanja Daerah (APBD) daerah setempat berdasarkan pengajuan kebutuhan masyarakat desa tersebut.

Desa Bululawang, Kecamatan Bululawang, Kabupaten Malang terdapat gejala yang ditemukan di lapangan, yaitu: (a) kurangnya transparansi struktur keanggotaan dan tugas LPMD Bululawang; (b) proses pembangunan desa Bululawang kurang melibatkan peran serta masyarakat desa sehingga masyarakat desa hanya mengetahui hasil dari pembangunan, tanpa 
mengetahui proses yang terjadi mulai dari musyawarah perencanaan hingga hasil musyawarah; (c) masyarakat desa Bululawang kurang mengetahui tingkat keberhasilan pelaksanaan pembangunan desa

Output dan tujuan suatu kegiatan yang telah direncanakan sangatlah berkaitan, efektifitas adalah hubungan antara output dan tujuan. Dalam artian efektivitas merupakan ukuran seberapa jauh tingkat output, kebijakan dan prosedur dari organisasi mencapai tujuan yang ditetapkan. Dalam pengertian teoritis atau praktis, tidak ada persetujuan yang universal mengenai apa yang dimaksud "Efektivitas". Bagaimana definisi efektivitas berkaitan dengan pendekatan umum. Bila ditelusuri efektivitas berasal dari kata dasar efektivitas yang artinya: (1) Ada efeknya (pengaruhnya, akibatnya, kesannya) seperti manjur; mujarab; mempan; (2) Penggunaan metode/cara, sarana/alat dalam melaksanakan aktivitas sehingga berhasil guna (mencapai hasil yang optimal) (Bungkaes, 2013)

Lembaga Pemberdayaan Masyarakat yang berada di tingkat kelurahan/desa yang bertugas sebagai mitra pemerintah dalam merencanakan, melaksanakan dan mengendalikan pembangunan desa/ kelurahan. Pemberdayaan masyarakat merupakan upaya pemerintah untuk mendorong akselerasi penurunan angka kemiskinan yang berbasis partisipasi yang diharapkan dapat menciptakan proses penguatan sosial yang dapat mengantar masyarakat miskin menuju masyarakat yang madani, sejahtera, berkeadilan, serta berlandaskan iman dan takwa (Sumodiningrat, 2009).

Dalam meningkatkan kemampuan dan potensi yang dimiliki masyarakat untuk berkembang, pemberdayaan masyarakat adalah upaya meningkatkan kemampuan dan potensi yang dimiliki masyarakat, sehingga masyarakat dapat mewujudkan jati diri, harkat dan martabatnya untuk bertahan dan mengembangkan diri secara mandiri baik itu di bidang ekonomi, sosial, agama, dan budaya. Pemberdayaan masyarakat terutama di pedesaan tidak cukup hanya dengan meningkatkan produktivitas, memberikan kesempatan usaha yang sama atau memberi modal saja, tetapi harus diikuti pula dengan perubahan struktur sosial, ekonomi masyarakat, mendukung berkembangnya potensi masyarakat melalui peningkatan peran, produktivitas, dan efisiensi (Widjaja, 2003)

Peran Lembaga Pemberdayaan Masyarakat Desa (LPMD) meliputi: (a) Memelihara kerukunan hidup warga masyarakat; (b) Membantu menjalankan tugas pelayanan kepada masyarakat yang menjadi tanggung jawab Pemerintah Desa; (c) Menyusun rencana pembangunan secara partisipatif; (d) Melaksanakan, mengendalikan, memanfaatkan, memelihara, dan mengembangkan pembangunan secara partisipatif; (e) Menggerakkan dan mengembangkan partisipasi, gotong royong dan swadaya masyarakat; (f) Menumbuh kembangkan kondisi dinamis masyarakat dalam rangka pemberdayaan masyarakat.

Pembangunan adalah upaya yang dilakukan secara sadar dan terencana, dilaksanakan terus menerus oleh pemerintahan bersama-sama segenap warga masyarakatnya atau dilaksanakan oleh masyarakat dengan di fasilitasi oleh pemerintahan, dengan menggunakan teknologi yang terpilih, untuk memenuhi segala kebutuhan atau memecahkan masalah-masalah yang sedang dan akan dihadapi, demi tercapainya mutu hidup atau kesejahteraan seluruh warga masyarakat dari suatu bangsa yang merencanakan dan melaksanakan pembangunan tersebut (Mardikanto, 2009).

Proses pengembangan atau pemberdayaan pada akhirnya akan menyediakan sebuah ruang kepada 
masyarakat untuk mengadakan pilihanpilihan sebab, manusia atau masyarakat yang dapat memajukan pilihan-pilihan dan dapat memilih dengan jelas adalah masyarakat yang mempunyai kualitas untuk mencapai tujuan yang dapat diberdayakan melalui kemandirianya, bahkan untuk lebih diberdayakan melalui usaha mereka sendiri dan akumulasi pengetahuan, keterampilan dan sumber lainya dalam rangka mencapai tujuan tanpa bergantung kepada orang lain (Darmawansyah, 2017).

Secara umum dalam melaksanakan tugasnya yaitu membantu Pemerintah Desa dan sebagai mitra dalam memberdayakan masyarakatdesa,tugaslembagakemasyarakatan meliputi menyusun rencana pembangunan secara partisipatif; melaksanakan mengendalikan, memanfaatkan, memelihara dan mengembangkan pembangunan secara partisipatif; menggerakkan dan mengembangkan partisipasi, gotong royong dan swadaya masyarakat; menumbuh kembangkan kondisi dinamis masyarakat dalam rangka pemberdayaan masyarakat (Bulele, 2015)

Dalam konsep pembangunan pedesaan salah satu hal yang penting untuk diperhatikan keberadaanya ialah adanya organisasi dalam unit desa yang bergerak dalam bidang pemberdayaan masyarakat desa. Organisasi-organisasi yang bergerak dalam bidang pemberdayaan masyarakat desa dapat dipahami sebagai motor penggerakterjadinyatransformasiinformasi yang dapat mengubah keterampilan masyarakat desa pada titik yang maksimal. Semakin maksimal keterampilan masyarakat desa maka akan berpengaruh pula terhadap laju pembangunan suatu desa. Keterampilan suatu masyarakat desa dapat dibentuk melalui berbagai kegiatan pemberdayaan masyarakat yang diprakarsai oleh masyarakat desa maupun aparatur desa, untuk memudahkan pengorganisiran pemberdayaan masyarakat desa maka keberadaan organisasi yang menaungi masyarakat desa dalam proses pemberdayaan menjadi mutlak diperlukan (Minarni, 2014)

Maka pembangunan itu merupakan proses yang terjadi secara bertahap dan berkelanjutan guna mewujudkan hal yang lebih baik seiring dengan dimensi waktu. Pada kenyataanya banyak programprogram pembangunan yang tidak sesuai dengan apa yang dibutuhan oleh masyarakat dikarenakan pemerintah belum mengopimalkan peranan masyarakat dalam proses perencanaan, pelaksanaan dan evaluasi. Dengan melalui Lembaga Pemberdayaan Masyarakat (LPM) yang merupakansalahsatulembagakemasyarakatan sebagai mitra kerja pemerintah desa untuk mengelola, merencanakan dan melaksanakan pembangunan dengan menggali swadaya gotong royongmasyarakatdesa.Pembangunan desa merupakan upaya pembangunan yang dilaksanakan di desa dengan ciri utama adanya partisipasi aktif masyarakat dan kegiatannya meliputi seluruh aspek kehidupan baik fisik material maupun mental spiritual (Muhtarom, 2016)

$$
\text { Menurut Pasal } 1 \text { Angka }
$$

Undang-Undang Nomor 6 Tahun 2014, Pembangunan Desa adalah upaya peningkatan kualitas hidup dan kehidupan untuk sebesar-besarnya kesejahteraan masyarakat Desa. Berdasarkan pendapat ahli di atas, maka pembangunan desa adalah suatu pembangunan yang diarahkan untuk meningkatkan taraf hidup masyarakat demi tercapainya mutu hidup atau kesejahteraan seluruh masyarakat suatu bangsa.

Penelitian terdahulu oleh (Faini, 2016) berjudul "Efektivitas Lembaga Pemberdayaan Masyarakat Desa dalam Mendukung Pembangunan di desa Kedunglumpang, Kecamatan Mojoagung, Kabupaten Jombang”. Diperoleh hasil bahwa berdasarkan observasi awal, sejauh ini pelaksanaan LPMD sebagai mitra dari pemerintahan desa masih kurang efektif dalam memberdayakan masyarakat. Dapat diketahui bahwa LPMD di Desa 
Kedunglumpang belum melaksanakan tujuan dari LPMD dalam mendukung pembangunan di Desa Kedunglumpang tersebut seperti tidak pernah melaksanakan kegiatan pemberdayaan masyarakat di bidang pembangunan desa.

Penelitian selanjutnya oleh Syaprianto dan Prihatin (2016) berjudul "Peranan Lembaga Pemberdayaan Masyarakat dalam Membantu Kepala Desa Menyusun Rencana Pembangunan Desa" diperoleh bahwa Kepala Desa dibantu oleh Lembaga Pemberdayaan Masyarakat Desa (LPMD) untuk membangun rencana pembangunan desa, sedangkan penelitian kali ini lebih mengarah pada tata cara pelaksanaan Lembaga Pemberdayaan Masyarakat Desa (LPMD) yang dibantu oleh masyarakat desa untuk melakukan pembangunan desa.

Penelitian ini bertujuan untuk mendeskripsikan efektivitas lembaga pemberdayaan masyarakat desa dalam pelaksanaan pembangunan masyarakat desa Bululawang, untuk mendeskripsikan kendala dari kinerja lembaga pemberdayaan masyarakat desa dalam pelaksanaan pembangunan desa Bululawang, Untuk mendeskripsikan solusi dari permasalahan kinerja lembaga pemberdayaan masyarakat desa dalam pelaksanaan pembangunan desa Bululawang.

\section{METODE}

Penelitian ini menggunakan jenis penelitian kualitatif dengan pendekatan deskriptif. Penelitian kualitatif adalah penelitian yang bermaksud untuk memahami fenomena tentang apa yang dialami oleh subjek penelitian yang misalnya perilaku, persepsi, motivasi, tindakan, dll, secara holistik, dan dengan cara deskripsi dalam bentuk kata-kata dan bahasa pada suatu konteks khusus yang alamiah dan dengan memanfaatkan berbagai metode ilmiah (Moleong, 2014) Metode penelitian kualitatif adalah metode penelitian yang berdasarkan pada filsafat positivism, digunakan untuk pada kondisi objek yang alamiah, dimana peneliti adalah sebagai instrument kunci, pengambil sumber data dilakukan secara purposive, teknik pengabungan dengan trianggulasi (gabungan), analisis data bersifat induktif/ kualitatif, dan hasil penelitian kualitatif lebih menekankan pada makna generalisasi (Sugiyono, 2014),

Penelitian ini berlokasi di Kantor dan masyarakat desa Bululawang. Proses penelitian berlangsung pada bulan Mei sampai dengan Juni 2019. Informan penelitian ini antara lain: (1) Penanggung Jawab Kepala Desa ; (2) Ketua Lembaga Pemberdayaan Masyarakat; (3) Sekretaris Lembaga Pemberdayaan Masyarakat; (4) Kaur Pembangunan dan Lingkungan Hidup Lembaga Pemberdayaan Masyarakat; (5) tiga tokoh masyarakat desa Bululawang.

Teknik pengumpulan data pada penelitian ini menggunakan: (1) Observasi partisipatif. Maksudnya, saat melakukan observasi peneliti terlibat dengan kegiatan sehari-hari orang yang diamati atau yang digunakan dalam sumber data penelitian. Sambil melakukan pengamatan, peneliti ikut melakukan apa yang dikerjakan oleh sumber data, dan ikut merasakan suka dukanya. Dengan menggunakan observasi partisipan ini, maka data yang diperoleh lebih lengkap, tajam dan sampai mengetahui pada tingkat makna dari setiap perilaku yang tampak. (2) Wawancara. Wawancara adalah percakapan dengan maksud tertentu. Percakapan itu dilakukan oleh dua pihak, yaitu pewawancara (interviewer) yang mengajukan pertanyaan dan terwawancara (interviewer) yang memberikan jawaban atas pertanyaan itu (Moleong, 2012). Wawancara dalam penelitian ini dilakukan pada pihak yang bersangkutan yakni pada lembaga pemberdayaan masyarakat desa dan masyarakat desa Bululawang. (3) Dokumentasi. Dokumen adalah fakta dan data yang tersimpan dalam berbagai bahan, 
yang tidak terbatas oleh ruang dan waktu sehingga memungkinkan bagi peneliti untuk mengetahui hal-hal yang pernah terjadi sebagai penguat data observasi dan wawancara dalam memeriksa keabsahan data, interpretasi, kesimpulan (Djaelani, 2013)

Teknik analisis data dalam penelitian ini terdapat empat cara analisis data kualitatif, yaitu pengumpulan data, reduksi data, penyajian data dan penarikan kesimpulan (Miles dan Humberman, 1992). Langkah selanjutnya yaitu uji keabsahan data. Keabsahan data diperlukan agar hasil penelitian menjadi terarah dan sesuai dengan data maupun fakta yang diperoleh dan dapat dipertanggung jawabkan. Setiap penelitian memerlukan standartnya untuk melihat derajat kepercayaan atau kebenaran dari hasil penelitiannya.

Dalam penelitian ini peneliti menggunakan teknik keabsahan data triangulasi sumber. Menggunakan teknik triangulasi sumber, peneliti membandingkan hasil wawancara yang diperoleh dari masing-masing sumber atau informan penelitian sebagai pembanding untuk mengecek kebenaran informasi yang didapatkan. Penelitian dikatakan objektif jika hasil penelitian telah disepakati banyak orang. Menguji konfirmabilitas berarti menguji hasil peneltian yang dihubungkan dengan proses penelitian. Konfirmabilitas yaitu apakah hasil penelitian dapat dibuktikan kebenarannya di mana hasil penelitian seseuai dengan data yang dikumpulkan dan dicantumkan dalam laporan lapangan. Peneliti perlu membuat kesepakatan dengan sumber data agar data yang diperoleh bersifat objektif. Pemeriksaan keabsahan data dilaksanakan dengan teknik yang berbeda. Contohnya data yang diperoleh peneliti dengan cara wawancara lalu dicek dengan observasi melalui pertanyaan-pertanyaan dan dokumentasi agar mendapatkan kepastian data mengenai evektivitas lembaga pemberdayaan masyarakat desa dalam pelaksanaan pembangunan desa.

\section{HASIL DAN PEMBAHASAN \\ Efektivitas LPMD dalam Pelaksanaan Pembangunan Desa Bululawang}

Efektivitas diartikan sebagai tingkat keberhasilan mencapai sasaran. Sasaran diartikan sebagai keadaan atau kondisi yang diinginkan. Sedangkan efisiensi adalah perbandingan terbaik antara input dan output, atau sering disebut rasio input dan output. Tingkat efektivitas juga dapat diukur dengan membandingkan antara rencana yang telah ditentukan dengan hasil nyata yang telah diwujudkan. Namun, jika usaha atau hasil pekerjaan dan tindakan yang dilakukan tidak tepat sehingga menyebabkan tujuan tidak tercapai atau sasaran yang diharapkan, maka hal itu dikatakan tidak efektif.

Melaksanakan pembangunan suatu perubahan ke arah kondisi yang lebih baik melalui upaya dan serangkaian kegiatan yang dilakukan secara terstruktur dan terencana oleh pemerintah dan masyarakat. Dalam hal ini LPMD desa Bululawang melaksanakan pembangunan atas dorongan dan keikut sertaan masyarakat desa Bululawang. Sebelum melaksanakan pembangunan yang bersifat infrastruktur harus dibangun dahulu kualitas sumber daya manusia agar membawa dampak positif. Hal tersebut tidak terlepas dari bagaimana peranan LPMD dalam melaksanakan pembangunan di desa Bululawang dengan memberdayakan sumber daya manusia yang bertujuan untuk meningkatkan partisipasi masyarakat dalam pelaksanaan pembangunan. Dari analisis wawancara di atas dapat ditarik kesimpulan bahwa perencanaan, pelaksanaan, dan pengendalian pembangunan yang dilaksanakan oleh LPMD di desa Bululawang dapat dikategorikan "Efektif".

Lembaga pemberdayaan masayarakat desa Bululawang dalam melaksanakan 
tugasnya sudah sesuai dengan Pasal 6 Peraturan Daerah Kabupaten Malang Nomor 16 Tahun 2006 tentang Lembaga Kemasyarakatan Desa. Hal ini dapat dilihat pada kegiatan rutinan yang dilaksanakan oleh LPMD desa Bululawang dan pemerintah desa lainnya bersama dengan masyarakat dalam menyusun rencana pembangunan secara partisipatif. Lalu lembaga pemberdayaan masyarakat desa Bululawang bersama dengan pemerintah desa lainnya melaksanakan, mengendalikan, memanfaatkan, memelihara dan mengembangkan pembangunan secara partisipatif. Mampu menggerakkan dan mengembangkan partisipasi, gotong royong dan swadaya masyarakat desa Bululawang. Lembaga pemberdayaan masayarakat desa Bululawang juga menumbuh kembangkan kondisi dinamis masyarakat dalam rangka pemberdayaan masyarakat.

Kunci kesuksesan pembangunan disuatu wilayah tergantung dari partisipasi pemerintah, masyarakat dan swasta yaitu perusahaan setempat. Yang kebanyakan terjadi adalah hanya baru ada peran dari pihak pemerintah, dan masyarakat. Partisipasi dari perusahaan masih sedikit, terlebih lagi pihak perusahaan yang mendasarkan bahwa belum ada kebijakan peraturan yang secara implisit meminta kepada perusahaan untuk berpartisipasi dalam pembangunan di masyarakat sekitar perusahaan (Lestari, 2015).

\section{Kendala dari Kinerja LPMD dalam Pelaksanaan Pembangunan Desa Bululawang}

Kendala yang terjadi pada permasalahan kinerja LPMD desa Bululawang masih terjadi. Pembangunan infrastruktur yang kurang merata dan masih belum mendapat perhatian dari lembaga desa dan pemerintahannya. Pembangunan non sarana dan prasarana juga masih belum maksimal, misal pada pelatihan kerajinan kayu rotan kemarin tidak ada tindak lanjut akan diarahkan kemana, seharusnya bias diarahkan menjadi UMKM agar perekonomian dan kualitas sumber daya manusia desa Bululawang semakin berkembang. Peningkatan partisipasi masyarakat dalam acara-acara yang diselenggarakan oleh pemerintah desa masih jauh dari kata baik.

Berbeda dengan hasil wawancara yang didapatkan dari pemerintah desa yang mengatakan bahwa kendala yang terjadi pada kinerja lembaga pemberdayaan masyarakat desa tidak dijumpai. Hanya saja apabila tidak ada rencana kegiatan oleh masing-masing bagian memang tidak ada keefektifan lembaga tersebut. Pada satu tahun masing-masing bagian tidak selalu memiliki kegiatan. Kemudian kendala yang terjadi pada masyarakat yaitu kurang guyub dalam berpartisipasi di kegiatan yang diselenggarakan desa, sehingga aparat desa harus bekerja dua kali.

\section{Solusi dari Permasalahan Kinerja Lembaga Pemberdayaan Masyarakat Desa Bululawang}

Solusi yang biasa ditawarkan yaitu lebih ditingkatkan lagi kerjasama dan dukungan yang baik antara pemerintah, lembaga pemberdayaan masyarakat desa, lembaga-lembaga desa yang lain, dan seluruh masyarakat desa Bululawang, sehingga kegiatan yang direncanakan dapat berjalan dengan optimal. Solusi yang kedua yaitu seluruh masyarakat harus dilibatkan dalam menyusun rencana pembangunan desa yang diutamakan seharusnya masyarakat yang masih awam agar partisipasi masyarakat dalam musyawarah RW ataupun musyawarah desa tersebut merata. Dan solusi terakhir yang bias ditawarkan yaitu meningkatkan langkahlangkah sosialisasi dari pemerintah desa, lembaga pemberdayaan masyarakat desa, dan lembaga-lembaga yang ada di desa terkait dengan permasalahan-permasalahan yang menghambat pembangunan desa 
secara partisipatif di desa Bululawang.

Berdasarkan tugas LPMD sebagai salah satu Lembaga Kemasyarakatan Desa terdapat pada Pasal 6 Peraturan Daerah Kabupaten Malang Nomor 16 Tahun 2006 tentang Lembaga Kemasyarakatan Desa, desa Bululawang mampu menyusun rencana pembangunan secara partisipatif bersama dengan masyarakat desa bululawang. Dalam hal melaksanakan, mengendalikan, memanfaatkan, memelihara dan mengembangkan pembangunan secara partisipatif desa Bululawang dapat mencapai tujuannya bersama dengan masyarakat desa Bululawang yang berpartisipasi dalam hal tersebut. Desa Bululawang dalam hal menggerakkan dan mengembangkan partisipasi, gotong royong dan swadaya masyarakat desa Bululawang sudah cukup baik. Serta lembaga pemberdayaan masyarakat desa Bululawang bersama dengan kepala desa Bululawang mampu menumbuh kembangkan kondisi dinamis masyarakat dalam rangka pemberdayaan masyarakat guna mencapai masyarakat yang mandiri.

Pemberdayaan masyarakat adalah upaya meningkatkan kemampuan dan potensi yang dimiliki masyarakat, sehingga masyarakat dapat mewujudkan jati diri, harkat dan martabatnya untuk bertahan dan mengembangkan diri secara mandiri baik itu di bidang ekonomi, sosial, agama, dan budaya. Pemberdayaan masyarakat terutama di pedesaan tidak cukup hanya dengan meningkatkan produktivitas, memberikan kesempatan usaha yang sama atau memberi modal saja, tetapi harus diikuti pula dengan perubahan struktur sosial, ekonomi masyarakat, mendukung berkembangnya potensi masyarakat melalui peningkatan peran, produktivitas, dan efisiensi. (Widjaja, 2003). Pelaksanaan lembaga pemberdayaan masyarakat desa dalam membangun partisipasi dan meningkatkan kualitas SDM sudah terlaksana dengan baik. Hal ini dapat dilihat dalam kemajuan tingkatan dan tamatan pendidikan masyarakat yang sudah lebih maju, peningkatan pendapatan ekonomi yang naik dari tahun ke tahun, dan pemberian fasilitas dari desa yang sudah memadai.

Keberdayaan masyarakat adalah dimilikinya daya, kekuatan atau kemampuan oleh masyarakat untuk mengidentifikasi potensi dan masalah serta dapat menentukan alternatif pemecahannya secara mandiri (Widjajanti, 2011) Keberdayaan masyarakat diukur melalui tiga aspek, yaitu:

1. Kemampuan dalam pengambilan keputusan

2. Kemandirian

3. Kemampuan memanfaatkan usaha untuk masa depan

Berdasarkan hasil penelitian dari (Hastuti, 2017) ditemukan bahwa LPMD di Desa Blorong terlibat dalam tahapan pembangunan desa mulai dari perencanaan, pelaksanaan, evaluasi, dan pemanfaatan hasil pembangunan namun belum optimal. Partsipasi LPMD sangat penting dalam menunjang pelaksanaan pembangunan dikarenakan sebagai lembaga perwakilan masyarakat yang menampung aspirasi masyarakat di bidang pembangunan dan mengetahui langsung mengenai kebutuhan dan permasalahan yang terjadi didalam masyarakat. Hal ini berbeda dengan hasil penelitian yang didapatkan di desa Bululawang, bahwa tingkat keefektifan LPMD desa Bululawang sudah berjalan dengan optimal. Keoptimalan LPMD desa Bululawang didukung oleh partisipasi masyarakat desa Bululawang mulai dari Musdes hingga Musrenbang bersama dengan Kepala Desa.

Proses Musrenbang jangan sampai disusun sebagai suatu acara seremonial yang separuh atau sebagian besar dadri waktunya di isi dengan sambutan-sambutan atau pidato-pidato. Inti Musrenbang adalah partisipasi aktif warga. Musrenbang desa 
adalah forum dialogis antara pemerintah desa dengan pemangku kepentingan lainnya untuk mendiskusikan atau menyepakati program pembangunan yang dapat memajukan keadaan desa. Dalam Musrenbang desa, pemerintah desa dan berbagai komponen warga bekerjasama memikirkan cara memajukan desanya melalui program pembangunan desa (Agustin, 2016)

\section{SIMPULAN}

Berdasarkan pembahasan di atas dapat disimpulkan bahwa efektivitas lembaga pemberdayaan masyarakat desa dalam pelaksanaan pembangunan desa Bululawang dalam pelaksanaannya ini dapat melaksanakan tugas, pokok, dan fungsinya dengan baik. Hal ini dapat dilihat dari berhasilnya pembangunan sarana dan prasarana maupun pembangunan non sarana dan prasarana. Kemudian kualitas sumber daya manusianya lebih maju dilihat dari tingkatan pendidikan, kondisi ekonomi, dan kerukunan umat beragama. Lembaga pemberdayaan masyarakat desa Bululawang dapat dikategorikan "efektif". Berdasarkan hasil penelitian yang telah diuraikan pada pembahasan sebelumnya, pelaksanaan lembaga pemberdayaan masyarakat desa dalam membangun partisipasi dan meningkatkan kualitas SDM sudah terlaksana dengan baik. Hal ini dapat dilihat dalam kemajuan tingkatan dan tamatan pendidikan masyarakat yang sudah lebih maju, peningkatan pendapatan ekonomi yang naik dari tahun ke tahun, dan pemberian fasilitas dari desa yang sudah memadai. efektivitas, dan efisiensi.

Berdasarkan pembahasan di atas dapat disimpulkan bahwa kendala dari permasalahan kinerja lembaga pemberdayaan masyarakat desa dalam pelaksanaan pembangunan desa Bululawang terdapat pada kurangnya partisipasi masyarakat mulai proses perencanaan hingga pengendalian pembangunan yang masih itu-itu saja partisipasinya, sehingga tidak terjadi pemerataan partisipan. Kendala selanjutnya terdapat pada pemerataan pembangunan yang belum bisa dikategorikan sebagai cukup baik karena masih banyak beberapa RT yang akses jalannya masih sulit. Juga pelatihan-pelatihan yang bersifat kewirausahaan belum ada tindak lanjut.

Berdasarkan pembahasan di atas dapat disimpulkan bahwa solusi yang ditawarkan dalam permasalahan tersebut antara lain, lebih menekankan langkahlangkah sosialisasi agar masyarakat yang awam tingkat partisipasinya meningkat, adanya tindak lanjut mengenai pelatihanpelatihan kewirausahaan yang telak dilaksanakan agar menjadi UMKM sehingga perekonomian masyarakat desa Bululawang menjadi lebih baik.

\section{DAFTAR PUSTAKA}

Agustin, Merry. 2016. Partisipasi Masyarakat dalam Perencanaan Pembangunan Desa Melalui Musrenbang (Studi Kasus Pada Pembangunan Japordes Desa Tunggunjagir Kecamatan Mantup Kabupaten Lamongan. Jurnal Publika. 4 (1) 1-14.

Bungkaes, H. R., Posumah, J. H., \& Kiyai, B. (2013). Hubungan Efektivitas Pengelolaan Program Raskin dengan PeningkatanKesejahteraanMasyarakat di Desa Mamahan Kecapatan Gemeh Kabupaten Kepulauan Talaud. Jurnal Acta Diurna. 2 (2) 1-23.

Bulele, Yoyo. 2015. Efektivitas Pelaksanaan Tugas Lembaga Pemberdayaan Masyarakat (LPM) dalam Perencanaan Pembangunan di Desa Bitunuris Kecamatan Salibabu Kabupaten Kepulauan Talaud. Jurnal Administrasi Publik, 1 (010) 1-23

Darmawansyah, Rizwan. 2017. Peran Lembaga Pemberdayaan Masyarakat (LPM) dalam Pemberdayaan 
Masyarakat di Desa Buniseuri Kecamatan Cipaku Kabupaten Ciamis. Jurnal Moderat. 3 (3) 1-12

Djaelani, Aunu. 2013. Teknik Pengumpulan Data dalam Penelitian Kualitatif. Jurnal Majalah Ilmiah Penelitian. 20 (1) $1-11$

Hardianto, dkk. 2016. Peranan Lembaga Pemberdayaan Masyarakat Desa (LPMD) dalam peningkatan Partisipasi Masyarakat terhadap Pembangunan di Desa Palasa Lambori Kecamatan Palasa Kabupaten Parigi Moutong. Jurnal Edu Civic. 4 (1) 1-17

Hastuti, Dwi., Rusnaini., dan Yuliandari. 2017. Partisipasi Lembaga Pemberdayaan Masyarakat Desa dalam Melaksanakan Pembangunan Desa Sebagai Perwujudan Civic Participatory di Desa Blorong Kecamatan Jumantono Kabupaten Karanganyar. Jurnal PKn Progresif. 12 (2) 623-633

Lestari, Sinta. 2015. Peran Lembaga Pemberdayaan Masyarakat terhadap Pelaksanaan Pembangunan Desa Benua Baru Kecamatan Muara Bengkal Kabupaten Kutai Timur. Jurnal Prediksi. 1 (2) 316-320

Mardikanto. 2009. Sistem Penyuluhan Pertanian. Sebelas Maret University Press. Surakarta.

Miles dan Huberman. 1992. Analisis Data Kualitatif. Jakarta: Universitas Indonesia Press

Minarni. 2014. Evaluasi Kinerja Lembaga Pemberdayaan Masyarakat Desa Untuk Meningkatkan Potensi Desa (Studi Pada Desa Blankahan Kecamatan Kuala Kabupaten Langkat Tahun 2013). Jurnal Perspektif. 7 (02) 374-391

Moleong, Lexy J. 2012. Metode Penelitian Kualitatif. Bandung: PT. Remaja Rosdakarya

Moleong, Lexy J. 2014. Metode Penelitian Kualitatif. Bandung: PT. Remaja Rosdakarya
Muhtarom, Abid. 2016. Peranan Lembaga Pemberdayaan Masyarakat (Lpm) Dalam Pembangunan Di Desa Di Kabupaten Lamongan. Jurnal Penelitian Ekonomi dan Akuntan, 1 (3) $181-204$

Peraturan Daerah Kabupaten Malang Nomor 16 Tahun 2006 tentang Lembaga Kemasyarakatan Desa

Setiawan dan Ilham. 2016. Peranan Lembaga Pemberdayaan Masyarakat Desa dalam Meningkatkan Pembangunan Pedesaan Terpadu (Studi Di Desa Pakatto Kecamatan Bontomarannu Kabupaten Gowa). Jurnal Tomallebi. 3 (1) 136-145

Sugiyono. 2014. Metode Penelitian Pendidikan Pendekatan Kuantitatif, Kualitatif, dan R\&D. Bandung: Alfabeta.

Sumodiningrat, Gunawan. 2009. Mewujudkan Kesejahteraan Bangsa. Elex Media Komputindo. Jakarta.

Syaprianto., dan Panca Setyo Prihatin. 2016.

Peranan Lembaga Pemberdayaan Masyarakat dalam Membantu Kepala Desa Menyusun Rencana Pembangunan Desa. Jurnal Pemerintahan, Politik dan Birokrasi. 2 (1) 59-70.

Widjajanti, Kesi. 2011. Model Pemberdayaan Masyarakat. Jurnal Ekonomi Pembangunan, 12 (1) 15-27 Rafsanzani, dkk. 2013. Kemitraan Lembaga Pemberdayaan Masyarakat Desa dengan Kepala Desa dalam Perencanaan Pembangunan Desa (Studi Kasus di Desa Sumber Ngepoh Kecamatan Lawang Kabupaten Malang). Jurnal Administrasi Publik. 1 (04) 67-72.

Undang-Undang Nomor 6 Tahun 2014 tentang Desa

Widjaja, A.W. 2003. Otonomi Desa Merupakan Otonomi Bulat, dan Utuh. Jakarta: PT Raja Grafindo Persada 